\title{
Los géneros literarios y la traducción. Aproximación a nuevas formas de creación literaria y traducción en tiempos de crisis
}

\author{
María Mercedes Enríquez Aranda \\ Universidad de Málaga \\ mmenriquez@uma.es \\ Inmaculada Mendoza García \\ Universidad Pablo de Olavide de Sevilla \\ imengar@upo.es \\ https://dx.doi.org/10.12795/futhark.2014.i9.04
}

\begin{abstract}
The study of literary genres plays an essential role in both the translator training and profession, as long as in his daily task the translator deals with texts exhibiting special genre conventions that are derived from specific cultural circumstances. The literary translator has to adapt himself/herself to the changes undergone by genres and it is by means of his/her ability for recreation that $\mathrm{s} /$ he will participate in this changing process. The result will be a translation placed within an ideal communication framework based on socially agreed rules and conventions, the translator playing a major role in their evolution. In this paper we present an update on the literary genres involved in the task of the literary translator in Spain in the 21st century. We also reflect on the impact of the current international crisis (financial, political, social and ethical values) on the publishing practices intrinsically linked to the literary translator.
\end{abstract}

Keywords: literary translation, translation theory, literary genres. 
Resumen: El estudio de los géneros literarios es de gran importancia tanto para la formación como para la profesión del traductor, ya que en su trabajo trata con textos que presentan unas convenciones genéricas especiales derivadas de circunstancias culturales concretas. El traductor hiterario se tiene que adaptar a los cambios que sufren los géneros y participar en ellos gracias a su capacidad de recreación. El resultado será entonces una traducción inserta en el marco de una comunicación feliz, basada en normas y convenciones consensuadas socialmente en cuya evolución el traductor desempeña un papel de primer orden. En este estudio presentamos una actualización de los géneros literarios con los que trabaja el traductor en la Espana del siglo XXI y reflexionamos acerca de la influencia que la actual situación de crisis internacional económica, política, sacial y de valores ejerce sobre las prácticas editoriales intrinsecamente ligadas al traductor literario.

Palabras clave: traducción literaria, teoría de la traducción, géneros literarios.

\section{INTRODUCCIÓN}

El estudio de los géneros literarios para el traductor resulta de especial relevancia. Los géneros se entienden como productos culturales en los que se han codificado las maneras en las que se expresan ciertos significados (Bustos Gisbert 2013, 35). Los textos que cumplen con funciones sociales similares y tienen características formales comunes se agrupan dentro de un mismo género. Conocer las convenciones genéricas es el primer paso para poder respetarlas (Bustos Gisbert $2005,18)$ y respetar estas convenciones implica comunicarse de acuerdo con unas normas lingüísticas obligatorias y unas leyes discursivas determinadas.

El traductor literario trata con textos que presentan unas convenciones genéricas especiales y variadas: los textos literarios propiamente dichos, los textos humanísticos, los textos periodísticos y los textos audiovisuales. Conocer las convenciones genéricas que siguen estos textos en su lengua original permite al traductor la comprensión completa del texto que va a traducir. Asimismo, conocer las convenciones genéricas que estos textos han de seguir en su lengua de traducción 
posibilita una traducción de acuerdo con ciertos rasgos linguísticos obligatorios y leyes discursivas particulares que varian según los géneros. Sin embargo, no ha de perderse de vista el carácter dinámico de los géneros, que varían sus formas de expresión de acuerdo con las necesidades de los usuarios en el devenir histórico (Bustos Gisbert $2013,35)$. El traductor literario ha de acomodarse a los cambios que sufren los géneros y participar en ellos gracias a su capacidad de recreación. El resultado será entonces una traducción inserta en el marco de una comunicación feliz, basada en normas y convenciones consensuadas socialmente en cuya evolución el traductor desempeña un papel de primer orden.

\section{LOS GÉNEROS LITERARIOS}

Hablar de los géneros literarios supone hablar de la propia naturaleza de la literatura. La obra literaria se ha de considerar un hecho comunicativo en el que participan todos los factores involucrados en la comunicación verbal, a saber, el hablante, el oyente, el mensaje, el contexto, el contacto y el código (Jakobson [1958], 19884, 32-39).

De acuerdo con Rodríguez Puértolas $(2000,294)$, las características que definen la comunicación literaria son las siguientes: 


\section{CARACTERISTICAS DE LA COMUNICACIÓN LITERARIA}

\begin{tabular}{|c|c|c|}
\hline Emisor & $\begin{array}{l}\text { Expresión de la sensibi- } \\
\text { lidad y vision del mun- } \\
\text { do de un autor }\end{array}$ & $\begin{array}{l}\text { Preferentemente indivi- } \\
\text { dual }\end{array}$ \\
\hline Receptor & Destinatario universal & \multirow[b]{2}{*}{ Lectura como recreación } \\
\hline Mensaje & \begin{tabular}{|l|} 
Carácter abierto \\
de la obra literaria \\
\end{tabular} & \\
\hline Contacto/Canal & $\begin{array}{l}\text { Perdurabilidad } \\
\text { e inalterabilidad }\end{array}$ & Preferentemente escrita \\
\hline Codigo & $\begin{array}{l}\text { Sin finalidad práctica } \\
\text { inmediata }\end{array}$ & $\begin{array}{l}\text { Creación artística } \\
\text { mediante la palabra }\end{array}$ \\
\hline \multirow{2}{*}{ Contexto } & \begin{tabular}{|l|}
$\begin{array}{l}\text { Función creativa o de- } \\
\text { miúrgica }\end{array}$ \\
\end{tabular} & $\begin{array}{l}\text { Autonomía de la obra } \\
\text { y ficcionalidad }\end{array}$ \\
\hline & Función mimética & Referencialidad \\
\hline
\end{tabular}

En realidad, la comunicación literaria, según Karam (2006, en línea), no deja de ser "una configuración dada por coordenadas específicas entre el emisor literario y el receptor".

Siguiendo a Mayoral (1999), Karam (2006, en línea) sintetiza las siguientes características propias de la comunicación literaria:

1. La comunicación literaria "se presenta en ausencia", esto es, el emisor y el receptor del mensaje no participan del espacio temporal.

2. Desde una perspectiva formal, "el mensaje tiene un cierto grado irreversible", en el sentido de que el receptor participa de manera diferente a la que lo hace el emisor de la comunicación literaria.

3. La comunicación literaria se diferencia de la comunicación "normal" en que la primera "tiene un carácter diferido como tal", esto es, la cadena de transmisión se produce en dos segmentos, emisormensaje y mensaje-receptor.

4. Todos los elementos del texto literario, tanto los elementos gráficos como los fonológicos, precisamente por presentarse dentro un 
contexto artístico, adquieren para el receptor un valor especial que perderían en el contexto de la comunicación no literaria.

El modelo segmentado de la cadena de transmisión de los textos literarios permite la interferencia de una serie de agentes mediadores que pueden modificar la esencia del mensaje del emisor. De hecho, "los textos se pueden traducir, plagiar, parafrasear, criticar, adaptar a otras culturas" (Karam 2006, en línea).

\subsection{CONCEPTO}

El término género literario nombra un concepto de difícil estudio sobre el que, a día de hoy, aún no se ha alcanzado acuerdo. Históricamente, han existido dos posturas principales al respecto:

1. El género literario es la descripción de las obras literarias de la Antigüedad clásica que la tradición ha consolidado y ha convertido en normas que los autores respetan o rompen según las épocas. A esta postura se la puede denominar clásica en tanto presupone la existencia de unos límites precisos y objetivos entre los géneros y acepta los moldes que le imponen obras anteriores consideradas modélicas. Esta primera gran teoría de los géneros literarios se debe al filósofo griego Aristóteles (s. IV a. C.).

2. El género literario define la actitud que el autor de la obra literaria adopta ante la materia que trata. A esta postura se la puede denominar romántica ya que reivindica la libertad del autor ante los moldes establecidos por la Antigüedad clásica y acepta la originalidad, la creatividad y la mezcla de géneros sin límite. Fue durante el Romanticismo (s. XVIII-XIX) cuando comenzó la negación del género literario como corsé restrictivo de la obra.

Paradójicamente, estas dos posturas parten de una base común: la consideración del género literario como una norma preceptiva que se acata o se transgrede.

Los estudios literarios actuales tienden a salvar esta dicotomía a favor de una concepción de género acorde a la comunicación artística que supone el hecho literario. Como Hernadi $(1978,144)$ defiende, la 
teoría de la literatura se ha de centrar en "el orden de la literatura y no en los límites entre los géneros literarios". En este sentido, los géneros literarios no se han de considerar preceptos o normas, sino configuraciones dinámicas que la tradición pone a disposición del autor para que este las reproduzca o las reinvente. La actividad artística resulta, desde este punto de vista, de la tensión existente entre las estructuras objetivas y la creatividad personal. Los géneros literarios son en sí mismos inestables, cambiantes y dinámicos.

\subsection{CLASIFICACIÓN}

La clasificación de los géneros literarios atiende a diversas denominaciones. Sin embargo, la cuestión terminológica es de segundo orden si los conceptos son claros. Siguiendo una de las opciones más conocidas, cabe distinguir entre tres conceptos:

1. Categorías genéricas (también llamadas géneros tradicionales): formas generales de estructuración consolidadas en la tradición literaria occidental. La distinción entre categorías genéricas se justifica por la actitud que el autor adopta ante el contenido que transmite:

- Lírica: predomina la función emotiva, la expresión del yo. Implica una visión subjetiva pura de la materia tratada. Suele estar escrita en verso. Tuvo su origen en Grecia y es posterior a la épica.

- Épica o narrativa: el autor trata la materia desde el exterior. Narra de forma objetiva las hazañas de héroes reales o imaginarios.

- Dramática: desaparece el autor por completo y se crea la ilusión de unos acontecimientos ajenos que suceden en presencia del público. Son obras literarias concebidas para representar ante un público una acción que varios personajes llevan a cabo mediante el diálogo.

2. Géneros literarios (también llamados subgéneros): realizaciones concretas de esas categorías en las que los elementos constitutivos adoptan una estructura particular definida de acuerdo con la 
intención del autor, su actitud ante la materia, sus necesidades comunicativas y la herencia de la tradición.

3. Géneros históricos (también llamados subgéneros): realizaciones concretas de esos géneros literarios en las que los elementos constitutivos adoptan unos rasgos de contenido, estructurales y lingüísticos generalmente ligados a una determinada época histórica.

Antecedentes de los géneros literarios tal cual hoy los conocemos o formas preliterarias nacidas de la necesidad elemental de expresión verbal son las formas simples que describe Spang (2000, 4557). Uno de sus rasgos característicos es la oralidad. Este puede ser un repertorio de algunas formas simples: el CASO (casus), el CHISTE (anécdota), el CUENTO DE HADAS (cuento fantástico o popular), el DICHO, el ENIGMA (acróstico, charade, rebus), la LEYENDA o VITA, el MEMORABILE, el MITO, la PARÁBOLA y la SAGA.

Los géneros fundamentales, según la tríada clásica de las categorías genéricas, se clasifican de la siguiente manera (Onieva Morales, 1992, Rodríguez Puértolas, 2000, 299-300 y Spang, 2000, 57-197):

\subsubsection{LÍRICA}

\begin{tabular}{|c|c|c|}
\hline \multirow{6}{*}{ 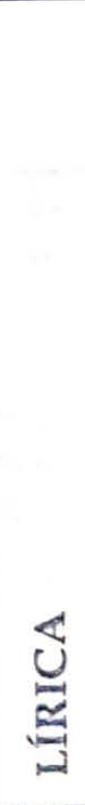 } & AFORISMO & $\begin{array}{l}\text { Sentencia breve y doctrinal que se propone } \\
\text { como regla. }\end{array}$ \\
\hline & \multirow{3}{*}{ CANCIÓN } & $\begin{array}{l}\text { De extensión variable, expresa habitualmente } \\
\text { emociones de tipo amoroso. }\end{array}$ \\
\hline & & $\begin{array}{l}\text { CANCIÓN POPULAR O TRADICIONAL: } \\
\text { brevedad y dinamismo de estructuras, sobrie- } \\
\text { dad y sencillez de sentimientos y de su expre- } \\
\text { sión. }\end{array}$ \\
\hline & & $\begin{array}{l}\text { CANCIÓN CULTA O PETRARQUISTA: tono } \\
\text { intimista e individualista, más extensa que la } \\
\text { popular y con métrica preceptuada. }\end{array}$ \\
\hline & ÉGLOGA & $\begin{array}{l}\text { Exposición de sentimientos amorosos y de } \\
\text { exaltación de la naturaleza, en boca de pastores. }\end{array}$ \\
\hline & ELEGÍA & $\begin{array}{l}\text { Poema extenso que expresa sentimientos de } \\
\text { dolor ante desgracias individuales o colectivas. }\end{array}$ \\
\hline
\end{tabular}




\begin{tabular}{|c|c|}
\hline EPIGRAMA & $\begin{array}{l}\text { Poema breve de forma no definida, de carácter } \\
\text { moral, comico o satirion. Puede tener dos fun- } \\
\text { ciones: alarde de ingenio o expresión de admi- } \\
\text { ración o critica. }\end{array}$ \\
\hline \multirow{4}{*}{ HINO } & $\begin{array}{l}\text { ración octitica. } \\
\text { Composición solemune destinada al canto (coral } \\
\text { o alternando voz y coro) que se utiliza para } \\
\text { expresar sentimientos patrióticos, religiosos, } \\
\text { guerreros... }\end{array}$ \\
\hline & $\begin{array}{l}\text { guerreros... } \\
\text { HIMNO LIRICO: celebra una victoria. }\end{array}$ \\
\hline & $\begin{array}{l}\text { HIMNO LIRICO: celeos } \\
\text { HIMNO LITUKRGICO: alabanza a Dios. } \\
\end{array}$ \\
\hline & $\begin{array}{l}\text { HIMNO LITURGIC : an } \\
\text { HIMNO NACIONAL: ensalza los ideales políti- } \\
\text { cos de una nación. }\end{array}$ \\
\hline ODA & $\begin{array}{l}\text { De cierta extensión y tono elevado, sirve al } \\
\text { poeta para expresar la emoción lírica que le } \\
\text { produce la contemplación de algo que le impre- } \\
\text { siona. }\end{array}$ \\
\hline $\begin{array}{l}\text { POEMA ESCENT- } \\
\text { CO }\end{array}$ & $\begin{array}{l}\text { siona. } \\
\text { Texto lírico-dramático de tono tragicómico, } \\
\text { satírico o burlesco. Es representable. }\end{array}$ \\
\hline SONETO & $\begin{array}{l}\text { satínico o burlesco. exs que posee unos esquemas métricos muy } \\
\text { severos (dos cuartetos y dos tercetos) y expresa } \\
\text { una actitud intelectual y reflexiva. }\end{array}$ \\
\hline $\begin{array}{l}\text { ANACREÓNTICA, } \\
\text { EPITALAMIO, IDII }\end{array}$ & $\begin{array}{l}\text { UADRO, EPITAFIO, } \\
\text { O, LETRILLA, MADRIGAL, SÁTIRA }\end{array}$ \\
\hline
\end{tabular}

\section{2 ÉPICA O NARRATIVA}

\begin{tabular}{|c|c|c|c|c|}
\hline 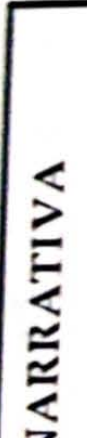 & $\begin{array}{l}\text { GÉNEROS } \\
\text { MAYORES }\end{array}$ & \begin{tabular}{|l} 
EN \\
VERSO
\end{tabular} & EPOPEYA & $\begin{array}{l}\text { Larga narración en verso } \\
\text { de hechos grandiosos y } \\
\text { memorables. Se reserva } \\
\text { esta denominación para las } \\
\text { que recogen antiguas } \\
\text { tradiciones de los pueblos: } \\
\text { la Biblia, La Iliada, La Odi- } \\
\text { sea... }\end{array}$ \\
\hline 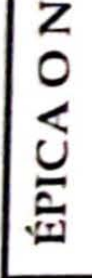 & & & & 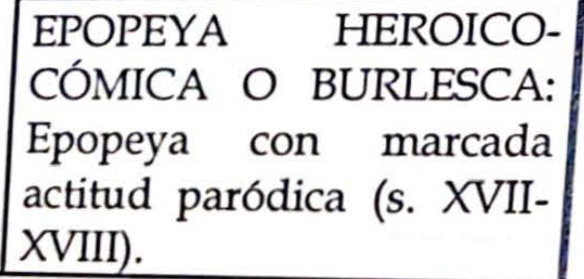 \\
\hline
\end{tabular}




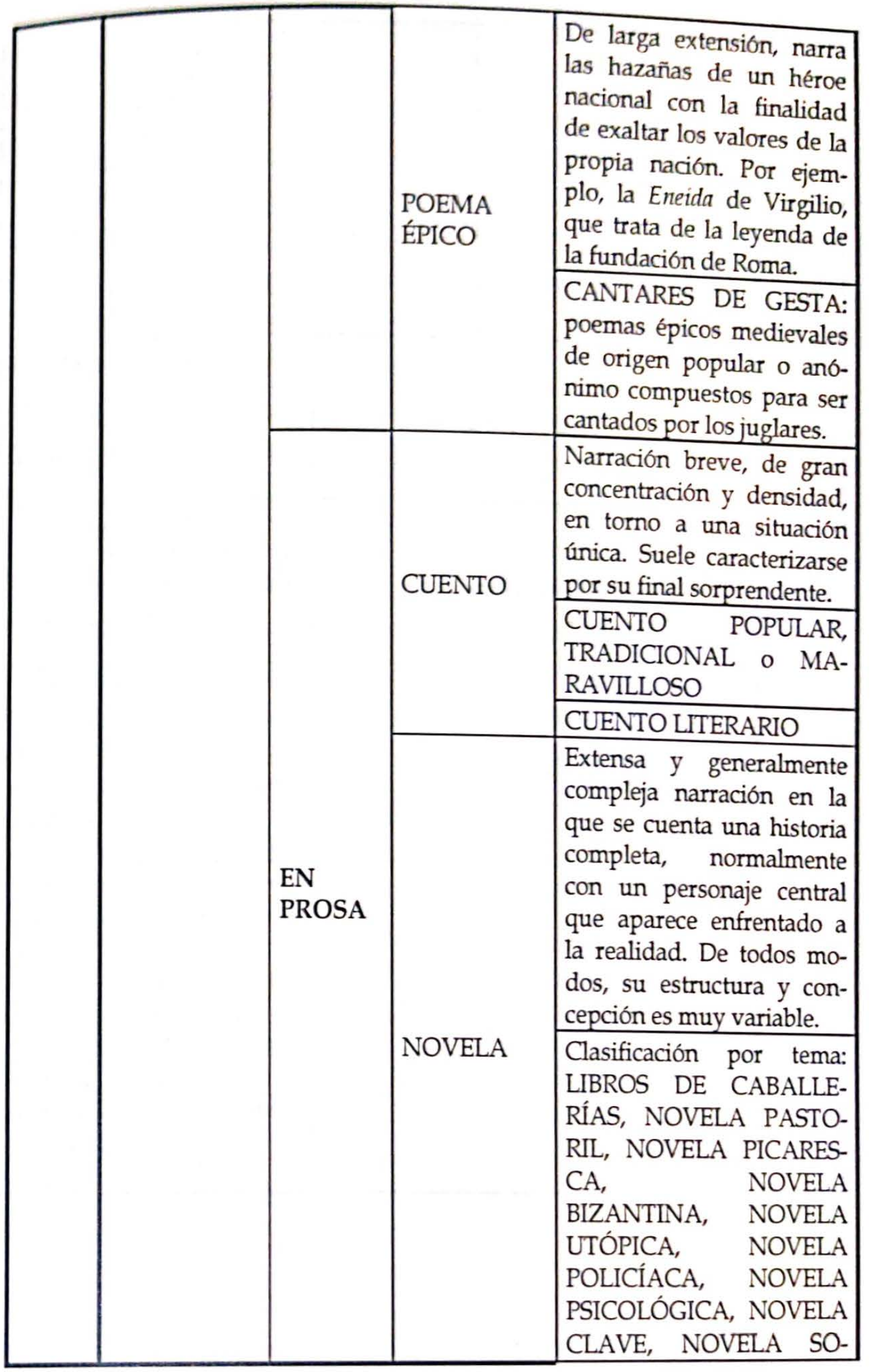




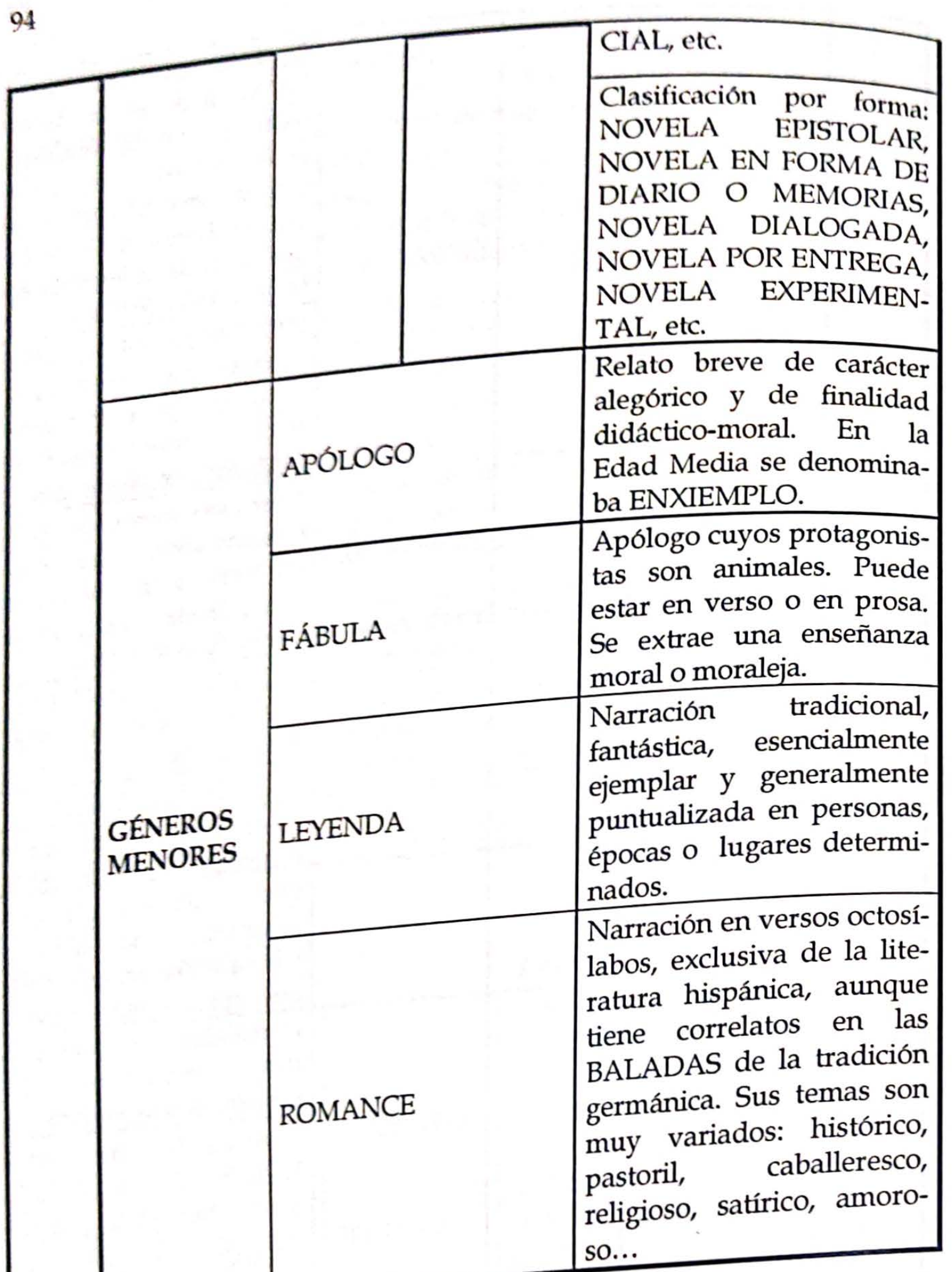




\begin{tabular}{|c|c|c|c|}
\hline \multirow{7}{*}{$=$} & \multirow{3}{*}{$\begin{array}{l}\text { GÉNEROS } \\
\text { MAYORES }\end{array}$} & COMEDIA & $\begin{array}{l}\text { Presenta conflicto o costumbres } \\
\text { de la vida cotidiana desde una } \\
\text { perspectiva humorística. Aun- } \\
\text { que puede plantear problemas } \\
\text { serios, se caracteriza por la } \\
\text { resolución feliz del conflicto. } \\
\text { COMEDIA DE CAPA Y ESPA- } \\
\text { DA, COMEDIA DE CARÁC- } \\
\text { TER, COMEDIA DE ENREDO, } \\
\text { COMEDIA DE FIGURÓN }\end{array}$ \\
\hline & & $\begin{array}{l}\text { DRAMA } \\
\text { O TRAGICOMEDIA }\end{array}$ & $\begin{array}{l}\text { Acción grave y conflictiva, a } \\
\text { menudo con final desdichado. } \\
\text { La lucha de los personajes care- } \\
\text { ce de heroísmo. Mezcla tension } \\
\text { con distensión e incluso comici- } \\
\text { dad. }\end{array}$ \\
\hline & & TRAGEDIA & $\begin{array}{l}\text { Relato protagonizado por un } \\
\text { héroe que, en conflicto con un } \\
\text { antagonista, se enfrenta a una } \\
\text { fuerza superior a él que lo lleva } \\
\text { a la catástrofe y a la dignidad. }\end{array}$ \\
\hline & \multirow{4}{*}{$\begin{array}{l}\text { GÉNEROS } \\
\text { MENORES }\end{array}$} & $\begin{array}{l}\text { AUTO SACRA- } \\
\text { MENTAL }\end{array}$ & $\begin{array}{l}\text { Se desarrolla en un acto, en } \\
\text { verso y con personajes alegóri- } \\
\text { cos. Termina con una exaltación } \\
\text { de la Eucaristía. }\end{array}$ \\
\hline & & ENTREMÉS & $\begin{array}{l}\text { Obra dramática corta de carác- } \\
\text { ter cómico y popular que solía } \\
\text { representarse en los entreactos } \\
\text { de las obras más largas (s. XVI- } \\
\text { XVIII). }\end{array}$ \\
\hline & & FARSA & $\begin{array}{l}\text { Obra cómico-satírica en la que } \\
\text { los caracteres de los personajes } \\
\text { están deliberadamente exagera- } \\
\text { dos. }\end{array}$ \\
\hline & & LOA & $\begin{array}{l}\text { Composición dramática breve, } \\
\text { pero con acción y argumento, } \\
\text { que se representaba antigua- } \\
\text { mente antes del poema dramáti- } \\
\text { co al que servía como preludio o }\end{array}$ \\
\hline
\end{tabular}






\section{LA TRADUCCIÓN LITERARIA}

La traducción es una realidad cultural de primera magnitud en todas las comunidades lingüísticas y, dentro del ámbito literario, "[...], ya desde la Edad Media la traducción ha asegurado la comunicación literaria entre las sociedades y civilizaciones de lenguas o idiomas diferentes" (García Peinado 2009, 108).

En las últimas décadas, los estudios sobre la traducción y, en particular, la teoría de la traducción, se han beneficiado de los estudios realizados en el campo de la lingüística en relación con la clasificación textual (Mercado López 2004, 5).

En este sentido, siguiendo a Hurtado Albir (2001, 58-59), los tipos de traducción vienen determinados por dos categorías principales:

1. Categoría de género: los tipos de traducción tienen que ver con la traducción de textos que pertenecen a determinados ámbitos socioprofesionales. Cada tipo de traducción se efectúa con géneros textuales característicos, entendidos como agrupaciones de textos pertenecientes a un mismo campo o modo y que comparten la función comunicativa, la situación de uso y las convenciones textuales. En este sentido también se expresa García Izquierdo $(2007,122)$, quien sostiene que los textos representan determinados ámbitos socioculturales y profesionales y que el género es la expresión tangible de las convenciones, tanto textuales como contextuales, que contienen dichos textos. De este modo, un género puede ser cualquier forma textual que se ajuste a unas convenciones socioculturales específicas, independien- 
temente de que pertenezca a un ámbito especializado o a un ámbito no especializado.

2. Categoría de campo: dada la importancia de los conocimientos extralingüísticos a la hora de traducir, los géneros textuales y los tipos de traducción vienen definidos por la variación lingüística según el marco socioprofesional (científico, técnico, legal...).

Siguiendo este razonamiento, cada tipo de traducción consta de géneros característicos pertenecientes a un ámbito socioprofesional determinado. Ahora bien, dentro de un mismo género, estas características suelen variar de una lengua a otra y de una cultura a otra (Mercado López 2004, 5). Por ello, la identificación de los géneros, el conocimiento de sus características dentro de una lengua determinada y la comparación de un mismo género entre lenguas diferentes son cuestiones de sumo interés para la comunidad traductora (Mercado López, 2004, 8).

De este modo, Hurtado Albir $(2001,58-59)$ habla de dos tipos de traducción:

1. Traducción de textos especializados: es la traducción de textos dirigidos a especialistas y pertenecientes a los llamados lenguajes de especialidad, por ejemplo, el técnico, el científico, el jurídico, el económico o el administrativo.

2. Traducción de textos no especializados: es la traducción de textos que no forman parte de los lenguajes especializados. Son los textos literarios y los textos no literarios, como los publicitarios o los periodísticos. Cada ámbito tiene sus características propias, relacionadas con el funcionamiento peculiar de los textos objeto de traducción: preferencias léxicas y sintácticas, rasgos intratextuales (coherencia y cohesión) y géneros.

\subsection{CARACTERÍSTICAS}

La traducción literaria pertenece, por tanto, a la traducción de textos no especializados. Los textos literarios son, en principio, su objeto 
de traduccion. Estos presentan unas características propias (Hurtado

Albir 2001, 62-65):

- Predominio de las características lingüístico-formales, lo cual

- Desviación respecto al lenguaje general.

- Creación de ficción.

- Diversidad de:

- Tipos textuales: narrativos, descriptivos...

- Campos temáticos: ocio, enseñanza, ciencia, administración, técnica...

- Tonos: modos particulares de expresión y de estilo según las diferentes relaciones interpersonales que se reflejan en el texto...

- Modos: mezcla de narración y diálogo...

- Estilos: dialectos (sociales, geográficos, temporales) e idiolectos...

- Referencias culturales en torno a la cultura y la tradición literaria de origen.

Las peculiaridades de los textos literarios determinan su traducción y condicionan el trabajo del traductor, quien debe poseer una competencia literaria definida por una serie de conocimientos y aptitudes:

- Amplios conocimientos literarios.

- Amplios conocimientos culturales.

- $\quad$ Aptitudes relacionadas con el funcionamiento de los textos: habilidad para la escritura, creatividad...

Esta competencia literaria permitirá al traductor enfrentarse a los problemas específicos que plantea la traducción de los textos literarios, que se pueden derivar de: 
- La sobrecarga estética: estilo, connotaciones, metáforas...

- El idiolecto propio del autor.

- La relación con las condiciones socioculturales del medio de partida.

- La intervención de la dimensión diacrónica (traducción de textos antiguos).

- Las convenciones propias de cada género literario. 


\subsection{TRADUCCIÓN LITERARIA Y TRADUCCIÓN DE TEXTOS LITERARIOS}

Pese a que el objeto de la traducción literaria ha quedado definido como los textos literarios, es conveniente realizar una puntualización terminológica introducida por primera vez en los estudios sobre la traducción por Toury (2004, [1995], 225-227). La expresión traducción literaria puede referirse a dos cuestiones distintas que Gallego Roca $(1994,166)$ nombra:

1. Traducción de textos literarios: La traducción de textos que se consideran literarios en la cultural original pero que pueden ser de cualquier otro tipo en la cultura de traducción. El trabajo del traductor está orientado, así, al texto original.

2. Traducción literaria: La traducción de cualquier tipo de texto de forma tal que el producto resultante sea considerado un texto literario en la cultura de traducción. El trabajo del traductor se orienta al texto traducido.

Por regla general, sobre todo si las culturas en las que los textos nacen son cercanas, los textos originales suelen ser literarios y dan lugar a textos traducidos también literarios. En el caso de culturas muy distantes entre sí, la diferenciación quizás sea necesaria y el traductor deberá ser consciente de las diferencias, aunque en la mayoría de los casos no dependa de él solo la elección de textos originales y su producto final en la cultura de traducción.

\section{REVISIÓN DE LOS GÉNEROS LITERARIOS}

Ahora nos hallamos con las herramientas necesarias para poder revisar el concepto y la clasificación de los géneros literarios.

A grosso modo, el género se entiende como una modalidad discursiva convencional y socialmente reconocida, de naturaleza sincrónica aunque con posibilidad de perdurar en el tiempo (Bustos Gisbert 2005, 19). 
La cuestion de la clasificación necesita matizaciones particulares. La clasificación de los géneros literarios según la tríada de categorías genéricas es comúnmente aceptada hoy en día. Sin embargo, la falta de acuerdo en torno al concepto de género literario se vuelve a dar en su clasificación, de tal manera que algunos tratados de retórica y poética señalan otras categorías genéricas que, al igual que las anteriores, también se justifican por la actitud del autor:

- Didáctica: el autor transmite una enseñanza al receptor. Géneros literarios didácticos son, por ejemplo, la EPÍSTOLA, los DIÁLOGOS medievales y renacentistas, los COLOQUIOS o el ENSAYO.

- $\quad$ Historia: el autor narra y analiza objetivamente hechos reales. Algunos géneros literarios históricos son las CRÓNICAS, las AUTOBIOGRAFÍAS y las MEMORIAS.

- Oratoria: el autor persigue convencer al público de un argumento razonado. Ciertos SERMONES y DISCURSOS se consideran géneros literarios oratorios.

Esta clasificación no está exenta de polémica. Por una parte, se duda del carácter puramente literario de los géneros adscritos a las diferentes categorías, ya que carecen de la ficcionalidad característica de la comunicación literaria. Por otra parte, las funciones didáctica, histórica y oratoria también están presentes en obras literarias pertenecientes a otras categorías genéricas, por lo que estas no deberían constituir por sí mismas unas categorías genéricas independientes.

De la bibliografía consultada al respecto se desprenden tres posturas teóricas.

1. Una primera postura conservadora, seguida por Spang (2000, 27-28), se acomoda a la clásica tríada de categorías genéricas. Con este posicionamiento no niega, sin embargo, el valor literario que tienen determinadas obras didácticas, históricas $\mathrm{u}$ oratorias. Tal es el caso dentro de la categoría genérica didáctica de los ensayos de Miguel de Unamuno. Pero considera que por sí mismas no son formas literarias aparte, como tampoco lo son lo cómico y lo trágico, funciones practicables en todos los géneros. 
2. Una segunda postura innovadora, seguida por García Berrio y Huerta Calvo (1992, 218-230), amplía la clasificación de los géneros literarios a los géneros didáctico-ensayísticos y se perfila así más afín al criterio contemporáneo del género literario como una realidad comunicativa cambiante.

3. Y una tercera postura mediadora, a medio camino entre las dos anteriores, expresada por Rodríguez Pequeño $(1995,64)$, según la cual las obras didácticas-ensayísticas son elevadas a categoría genérica, pero considera que dentro de esta categoría existen obras literarias y obras no literarias

El debate está servido una vez más. El concepto y la clasificación de los géneros literarios es un terreno de estudio complejo que da pie a muy variadas interpretaciones. Sin embargo, a los efectos de nuestro interés principal, esto es, los géneros literarios en relación con su traducción, la postura ha de ser necesariamente integradora.

Dadas las características de la comunicación literaria (carácter abierto de la obra literaria), de los géneros literarios (configuraciones dinámicas y cambiantes) y de la traducción literaria (creatividad del proceso traductor), a las que hay que sumar el estado del mercado de la traducción literaria en la España actual (objeto de estudio del siguiente epígrafe), se hace conveniente, si no necesario, establecer una toma de posición muy concreta con la que no entramos a discutir cuestiones teóricas que no repercuten en la práctica de la profesión. Este criterio consiste en incluir en nuestro estudio de los géneros literarios aquellas obras que presentan un carácter literario o pseudoliterario que requieren del traductor profesional una competencia literaria en el ejercicio de su profesión. Los textos a los que nos referimos son los textos humanísticos, los textos periodísticos y los textos audiovisuales.

\subsection{TEXTOS HUMANÍSTICOS}

Los textos humanísticos engloban aquellos textos que tradicionalmente han sido considerados fuera del ámbito de las poéticas porque tratan de materia doctrinal y no ficcional. El propósito estético se 
subordina a fines ideologicos, aunque nunca termina de desaparecer. García Berrio y Huerta Calvo (1992, 218-230) aúnan en su clasificación de los géneros didáctico-ensayísticos las categorías genéricas que antes habíamos agrupado según la actitud del autor hacia su obra, esto es, la didáctica, la historia y la oratoria.

\begin{tabular}{|c|c|c|c|c|c|}
\hline \multirow{3}{*}{ ( } & \multirow{3}{*}{$\begin{array}{l}\text { DE EXPRE- } \\
\text { SION DRA- } \\
\text { MÁTICA } \\
\text { (dramática) }\end{array}$} & \multirow{3}{*}{\multicolumn{2}{|c|}{ DIÁLOGO }} & \multirow{2}{*}{\multicolumn{2}{|c|}{$\begin{array}{l}\text { PLATÓNICO: carácter filosofico. } \\
\text { CICERONIANO: exposición de } \\
\text { conocimientos necesarios al orador } \\
\text { ideal. }\end{array}$}} \\
\hline & & & & & \\
\hline & & & & LUCIANESCO & $\begin{array}{l}\text { SÁTIRA MENI- } \\
\text { PEA: introduce } \\
\text { elementos imagi- } \\
\text { narios. } \\
\end{array}$ \\
\hline \multirow{5}{*}{ 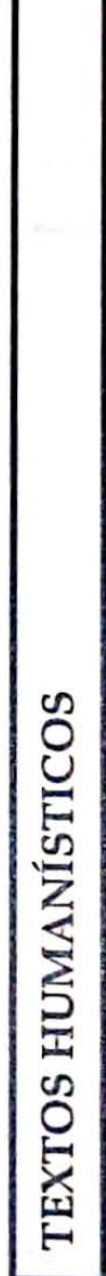 } & \multirow{5}{*}{$\begin{array}{l}\text { DE EXPRE- } \\
\text { SION OBJE- } \\
\text { TIVA } \\
\text { (épica } \\
\text { o narrativa) }\end{array}$} & \multirow{5}{*}{\multicolumn{2}{|c|}{$\begin{array}{l}\text { FORMAS ESCRI- } \\
\text { TAS }\end{array}$}} & ENSAYO & $\begin{array}{l}\text { De temática } \\
\text { variada, el autor } \\
\text { expresa su opi- } \\
\text { nión subjetiva en } \\
\text { una prosa litera- } \\
\text { ria sin estructura } \\
\text { prefijada. }\end{array}$ \\
\hline & & & & & \begin{tabular}{|ll} 
ARTÍCULO, \\
RESENAA, PO- \\
NENCIA \\
\end{tabular} \\
\hline & & & & $\begin{array}{l}\text { GLOSA DOC- } \\
\text { TRINAL }\end{array}$ & $\begin{array}{l}\text { De materia místi- } \\
\text { ca. }\end{array}$ \\
\hline & & & & TRATADO & $\begin{array}{l}\text { Obras en prosa } \\
\text { de ficción u obras } \\
\text { cientificas y di- } \\
\text { dácticas. }\end{array}$ \\
\hline & & & & $\begin{array}{l}\text { MISCELÁNEA } \\
\text { (ENSAYO, } \\
\text { NOVELA y } \\
\text { APOTEGMA) }\end{array}$ & $\begin{array}{l}\text { APOTEGMA, } \\
\text { REFRÁN, MÁ- } \\
\text { XIMA, AFORIS- } \\
\text { MO, GREGUE- } \\
\text { RÍA: Pensamiento } \\
\text { fragmentario y } \\
\text { reflejo del folclo- } \\
\text { re. }\end{array}$ \\
\hline
\end{tabular}

Futhark 9 (2014)

Enriquez y Mendoza, Los géneros literarios, 85-120

ISSN $1886-9300$ 


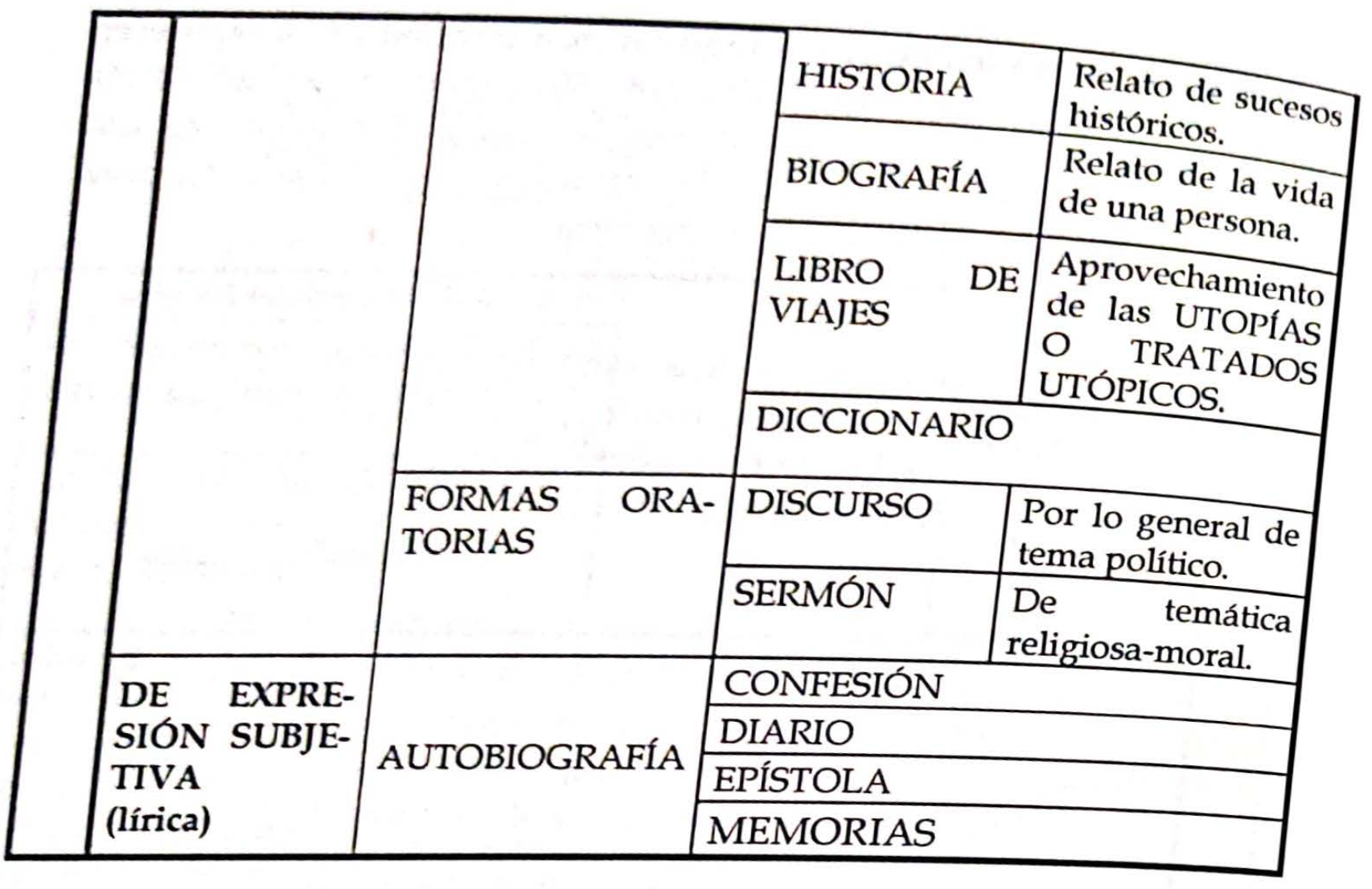

\subsection{TEXTOS PERIODÍSTICOS}

Los textos periodísticos son textos de comunicacion social que se transmiten a través de canales como la prensa, la radio, la televisión, el cine o las redes informáticas. El medio de comunicación social escrita más destacado es el periodismo escrito. El mensaje periodístico debe tener las siguientes características:

- $\quad$ Fidelidad a la información.

- Afán de veracidad y objetividad.

- Proximidad y actualidad de las noticias.

- Diversidad en los mensajes de información.

- Interés para el público lector.

La información se puede transmitir en estilos diferentes y con intenciones diferentes, pero es fundamental que el receptor del texto pueda comprenderla con facilidad. Es por ello que un texto periodístico debe estar redactado en un estilo claro, conciso y sencillo, y estas 
mismas premisas estilisticas deben también primar en la traducción del texto periodístico si queremos que la informacion se transmita con fluidez (Hernández Guerrero 2006, 126).

De acuerdo con Martín Duque y Fernández Cuesta $\left(1988^{12}, 85\right)$, las finalidades del periodismo son dos: informar y formar. En torno a estas dos finalidades se pueden estructurar los géneros periodísticos (Hernández Guerrero 2005, 90-92):

\begin{tabular}{|c|c|c|c|}
\hline & \multirow[t]{2}{*}{ INFORMATIVOS } & \begin{tabular}{|l|l|} 
& \\
NOTICIA \\
o INFORMA- \\
CIÓN
\end{tabular} & $\begin{array}{l}\text { Relato objetivo de hechos } \\
\text { o sucesos novedosos que } \\
\text { son de interés general. } \\
\text { Suele seguir una estruc- } \\
\text { tura de pirámide inverti- } \\
\text { da, con información de } \\
\text { mayor a menor impor- } \\
\text { tancia. }\end{array}$ \\
\hline & & ENTREVISTA & $\begin{array}{l}\text { Reproducción de una } \\
\text { conversación entre el } \\
\text { periodista y un persona- } \\
\text { je. }\end{array}$ \\
\hline \multirow{3}{*}{ 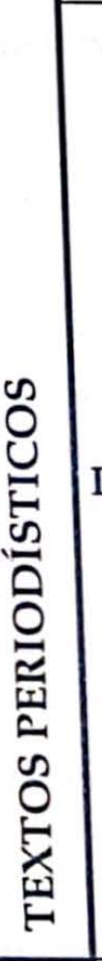 } & \multirow{3}{*}{ INTERPRETATIVOS } & $\begin{array}{l}\text { INFORME PE- } \\
\text { RIODÍSTICO }\end{array}$ & $\begin{array}{l}\text { Selecciona información } \\
\text { para suscitar en el desti- } \\
\text { natario la necesidad de } \\
\text { interpretar la actualidad, } \\
\text { ofreciéndole datos para } \\
\text { ello. }\end{array}$ \\
\hline & & REPORTAJE & $\begin{array}{l}\text { Relato objetivo de hechos } \\
\text { o sucesos novedosos que } \\
\text { son de interés general } \\
\text { más amplio que la noti- } \\
\text { cia. El estilo es narrativo } \\
\text { y creador. } \\
\end{array}$ \\
\hline & & CRÓNICA & $\begin{array}{l}\text { Texto informativo amplio } \\
\text { elaborado por un corres- } \\
\text { ponsal fijo o por un en- } \\
\text { viado especial al lugar } \\
\text { del acontecimiento. Suele } \\
\text { estar subordinada a una } \\
\text { noticia relevante. }\end{array}$ \\
\hline
\end{tabular}

Futhark 9 (2014) Enríquez y Mendoza, Los géneros literarios, 85-120 ISSN $1886-9300$ 


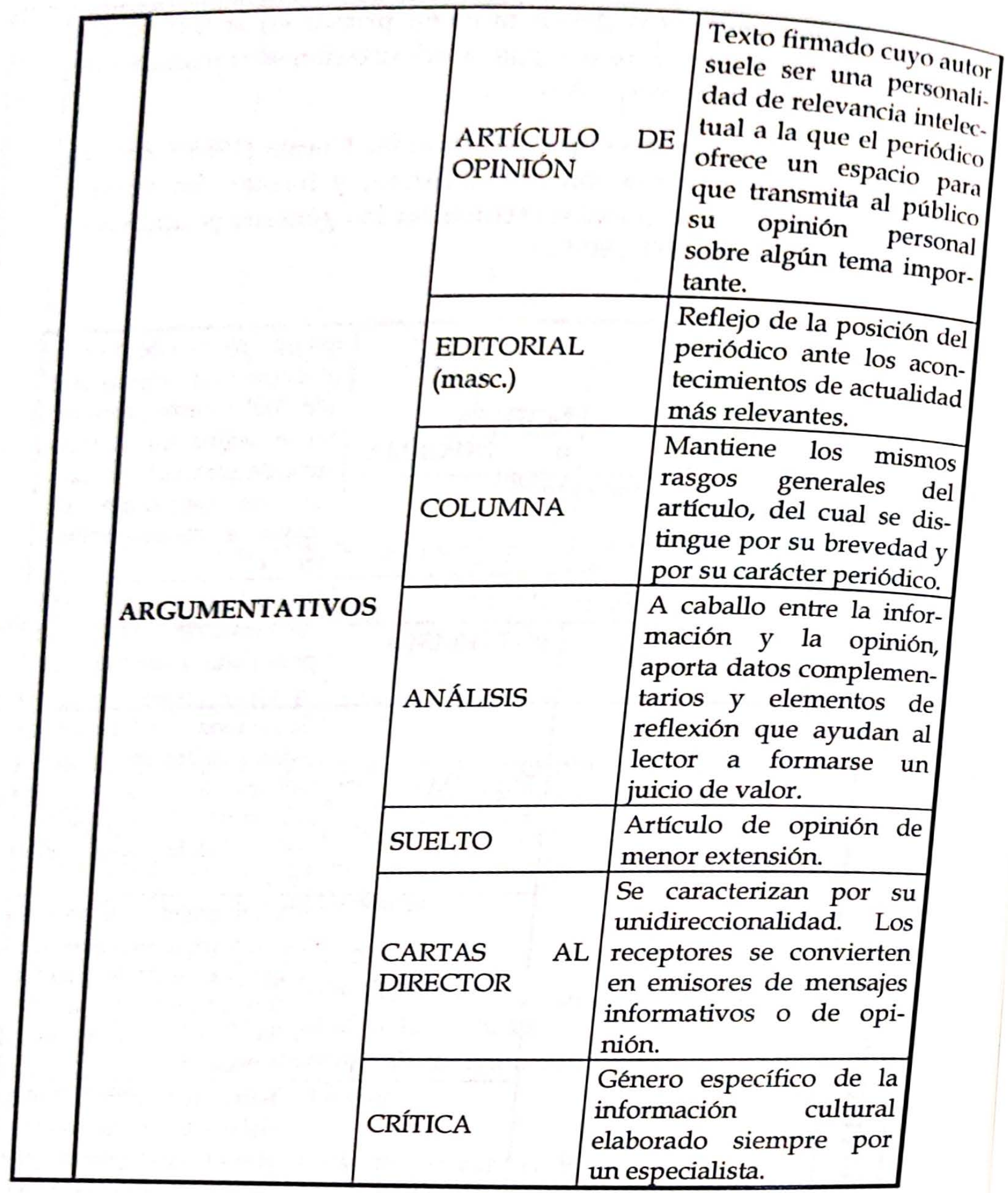

No obstante, conviene indicar que esta clasificación tradicional de los textos periodísticos está siendo sometida a un constante debate en 
el ámbito académico. Algunos investigadores consideran esta tipología desfasada e insostenible (Martínez Hernando 1998, 51-60). Otros consideran que los continuos cambios que se producen en la forma de redactar la informacion han supuesto, en muchas ocasiones, la ruptura de las fronteras tradicionalmente establecidas entre los diferentes tipos de géneros periodísticos, con el consecuente incremento de su tipología y de sus subgéneros, en un intento de abarcar el amplio despliegue expresivo presente en los medios de comunicacion (Fontcuberta 1993, 102-108). En la misma línea, Gomis (1989, 129-141) sostiene que los géneros son el reflejo de la evolución del periodismo, puesto que se van modificando al mismo tiempo que varían las demandas de la sociedad y los objetivos de la profesión periodística. En este sentido, los géneros y los subgéneros periodísticos se configuran como un sistema de interpretación continua de la realidad social.

Lo que se cuestiona, por tanto, es la validez de la clasificación convencional, pero no la existencia de los géneros periodísticos. De hecho, Martínez Albertos $(1996,2)$ no concibe una formación adecuada en periodismo sin la existencia de una teoría precisa de géneros periodísticos. Desde una perspectiva académica y metodológica, tanto en el ámbito pedagógico como en el profesional, para poder analizar y valorar correctamente los textos periodísticos es necesario clasificar determinados productos culturales. También Gomis (1989, 129-141) considera la clasificación de los géneros y los subgéneros periodísticos un instrumento pedagógico fundamental para el ejercicio de la profesión puesto que sirven de modelos y esquemas de referencia en el proceso de aprendizaje.

Estas consideraciones acerca de la taxonomía de los géneros periodísticos afectan directamente al traductor de esta tipología textual, dado que para poder traducir estos géneros y subgéneros periodísticos el traductor debe ser capaz de diferenciar sus rasgos y sus convenciones textuales dentro de cada una de las lenguas y culturas con las que trabaja.

De este modo, podemos afirmar que cada uno de los géneros anteriores presenta unas convenciones textuales predeterminadas, una forma específica de comunicar mediante el uso de unas estructuras diferentes: "Cada género se diferencia de los demás por su estilo y la 
utilización de los recursos lingüísticos, su finalidad y la disposición psicológica del autor" (Hernández Guerrero 2006, 127). Ahora bien, estas convencionales textuales propias de cada género varían, sin embargo, de una lengua y de una cultura a otra puesto que "Las convenciones que rigen para la confección de una variedad textual en un sistema sociocultural determinado no tienen por qué coincidir con los patrones textuales de otros sistemas" (Hernández Guerrero 2006, 127). Por ello, para traducir géneros periodísticos, el traductor debe haber desarrollado previamente unas competencias especificas, a saber: unos conocimientos textuales especializados, un dominio de las convenciones y unas técnicas propias de la redacción y del estilo periodísticos.

\subsection{TEXTOS AUDIOVISUALES}

Los textos audiovisuales se caracterizan porque en ellos confluyen dos códigos: el lingǘstico y el visual. $E$ incluso a veces integran el código musical. Al igual que los textos periodísticos, los audiovisuales son textos de comunicación social y, también como ellos, los canales a través de los que se transmiten son el cine, el vídeo, el DVD, la televisión, los ordenadores o las consolas de videojuego.

De acuerdo con Sokoli $(2005,182)$, las características que diferencian el texto audiovisual de otros textos y que por lo tanto condicionan su traducción se pueden sintetizar de la siguiente manera:

1. Recepción por dos canales: acústico y visual.

2. Presencia significativa de elementos no verbales.

3. Sincronía entre elementos verbales y no verbales.

4. Transmisión por pantalla: reproducibilidad.

5. Secuencia predeterminada de imágenes y sonido: material grabado.

La clasificación que Agost (1999) hace de los textos audiovisuales es la siguiente: 


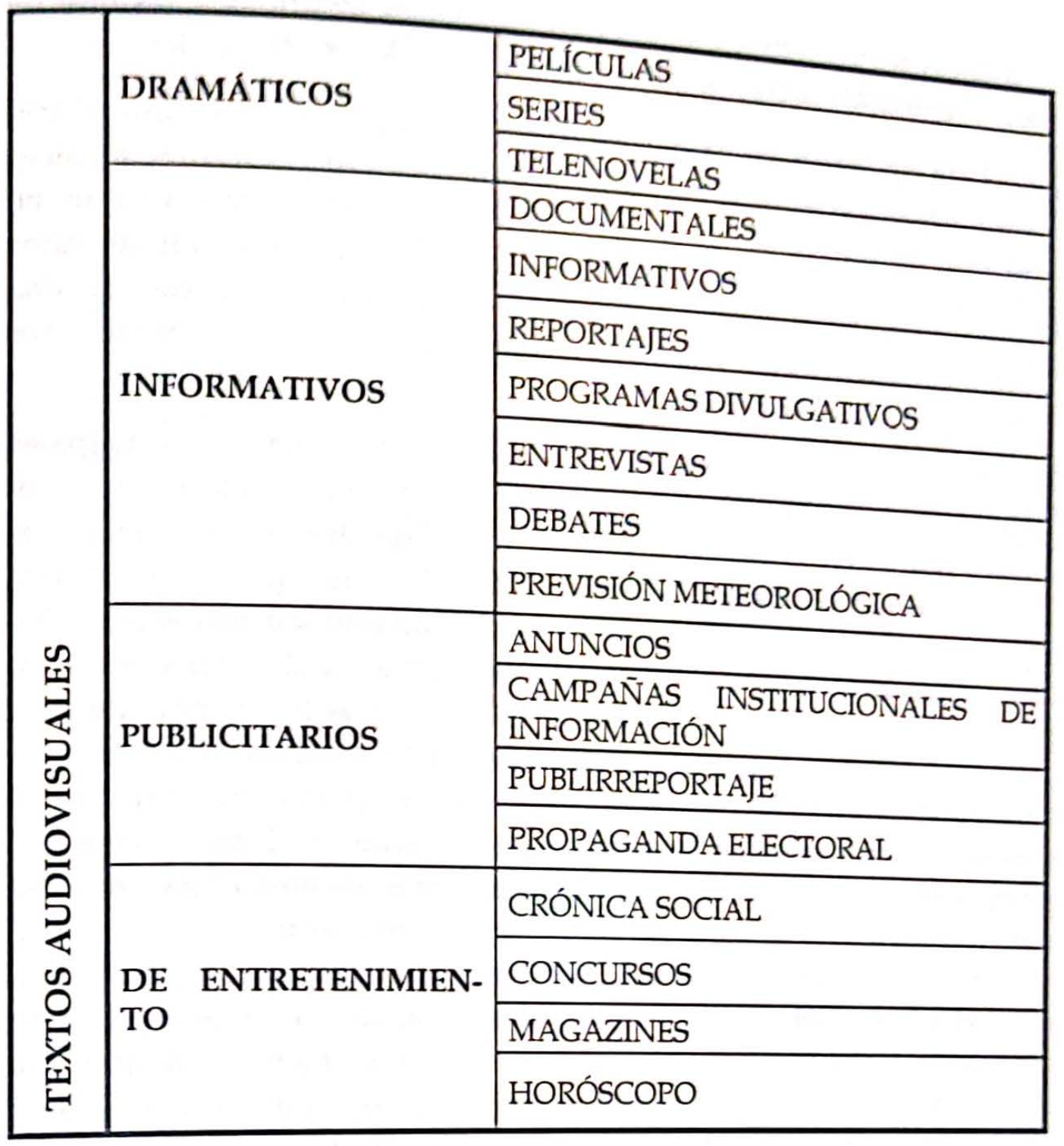

\section{PANORAMA DE LA TRADUCCIÓN DE LOS GÉNEROS LITERARIOS EN LA ESPAÑA DEL SIGLO XXI: CREACIÓN Y CRISIS}

El mercado no engaña y las cifras demuestran que el traductor literario dedica parte su producción traductora no solo a las categorías genéricas tradicionales - lírica, narrativa y dramática - , sino que cada vez con más frecuencia, dirige su atención a textos humanísticos, periodísticos y audiovisuales.

Futhark 9 (2014)

Enríquez y Mendoza, Los géneros literarios, 85-120

ISSN 1886-9300 
Estos textos requieren de él competencias añadidas a las que de por sí demanda la traducción de textos literarios tradicionales.

Para los textos periodísticos, recordamos, por ejemplo, que el traductor necesita unos conocimientos textuales especializados, técnicas de redacción periodística y dominio de las convenciones, ya que, en palabras de Hernández Guerrero (2006, 129), "el traductor de estos géneros construye nuevos textos periodísticos que se insertan en una tradición lingüística y cultural específica, que se rige por parámetros diferentes a la del original".

En la traducción periodística confluyen dos factores principales que determinan la labor del traductor: las mismas prácticas profesionales que rigen el periodismo y un modo de discurso específico, el periodístico (Hernández Guerrero 2008). Por una parte, la práctica profesional periodística impone las formas de traducir textos periodísticos. Por otra parte, el traductor de este género debe conocer las características propias de esta variedad textual. Los textos periodísticos se rigen por unas convenciones textuales determinadas que el traductor periodístico debe conocer en profundidad para conseguir que su producto de traducción funcione correctamente en el nuevo contexto lingüístico y cultural en el que se recibe. "En ocasiones, el traductor ha de trabajar como lo haría un periodista. $Y$ en algunos casos, los traductores de textos periodísticos son los propios periodistas" (Hernández Guerrero 2008). Hay que tener en cuenta, además, que en el plano estilístico los textos periodísticos suelen ser textos muy elaborados, a veces muy próximos incluso a los textos literarios; que suelen versar sobre temas muy variados, en ocasiones con un importante grado de especialización, y que están intrínsecamente relacionados con la realidad social y política de la cultura origen. "La suma de estos y otros factores hace necesaria la presencia de traductores casi humanísticos, podríamos decir, con un amplio bagaje de conocimientos lingüísticos y culturales para garantizar el éxito de la traducción" (Hernández Guerrero 2008).

En el caso de los textos audiovisuales, el traductor ha de lidiar con diversas peculiaridades: 
- Los canales: auditivo y visual.

- Los tipos de señales de la traducción audiovisual: imagen en movimiento, imagen fija, texto, diálogo, narración, música y ruido.

- La autoría compartida de la traducción: actores, director de doblaje, director de subtitulado, ajustadores...

- Las convenciones propias del género que se dan entre el producto traducido y el espectador: en el doblaje, la sincronía visual, y en el subtitulado, las convenciones ortotipográficas, por ejemplo.

Estas son algunas de las dificultades que, según Mayoral Asensio (2001,34-37), el traductor literario tiene que afrontar para que el producto traducido se pueda percibir en mayor o menor grado como un producto original.

A estos rasgos añade Chaume (2001, 86-87) lo que denomina "una oralidad prefabricada". Las características lingüísticas de este género no son las mismas que las del lenguaje oral espontáneo puesto que, en realidad, "el discurso oral de los personajes en pantalla no es más que el recitado de un discurso escrito anterior" (Chaume 2001, 78-79). Los textos audiovisuales se caracterizan por la presencia de un lenguaje elaborado no solo porque el registro oral no es más pobre que el registro escrito, sino porque además se trata de un lenguaje oral especial que se mueve entre dos registros diferentes: el registro coloquial y el denominado registro formal neutro. Por todo ello, una de las mayores dificultades del traductor de esta variedad textual es no caer en la tentación de imitar un registro oral espontáneo y encontrar el equilibrio entre las convenciones normativas de los clientes - que se basan en parámetros de recepción, históricos, políticos y socioculturales- y la oralidad propia de los textos audiovisuales (Chaume 2001, 87).

Para los textos humanísticos, en la frontera genérica con la tríada clásica, valga lo dicho para los textos literarios, e insístase - para estos y para todos en general - en que el traductor literario se halla obligado a conocer no solo los patrones textuales de su propio sistema sociocultural, sino también el resto de las convenciones propias de los géneros que traduce.

Futhark 9 (2014)

Enríquez y Mendoza, Los géneros literarios, 85-120

ISSN $1886-9300$ 
En los últimos años, el incremento del volumen de traducciones en el mercado editorial ha generado una concienciación cada vez mayor de la profesión del traductor. Fruto de la preocupación que despiertan unas condiciones laborales mejorables son los estudios que se han elaborado en torno a la problemática profesional del traductor de libros. Información y denuncia son sus dos principales objetivos.

Para el tema que nos ocupa, resultan interesantes los datos que aportan, por un lado, Rodríguez Morató $(1997,29-31)$ y, por otro lado, la Sección Autónoma de Traductores de Libros de la Asociación Colegial de Escritores de España (ACE Traductores, de aquí en adelante) en su Libro Blanco de la traducción en España (LBTE) del año 1997 (42-44) y del año 2010 (45-52). ${ }^{1}$

1 Otros estudios relacionados son: ACE Traductores (2003): "Informe sobre la situación del traductor de libros en España", Vasos comunicantes (Madrid), 25, 39-64 (vers. integra <http://www.acett.org> y ESCOBAR, Julia (1998): "La traducción y la interpretación en español", en Dirección Académica del Instituto Cervantes (coord.): El español en el mundo. Anuario del Instituto Cervantes. 1998, Madrid, Arco Libros-Instituto Cervantes, 13-57. 
GRÁFICO. La práctica de los diferentes géneros (Rodríguez Morato, 1997,29)

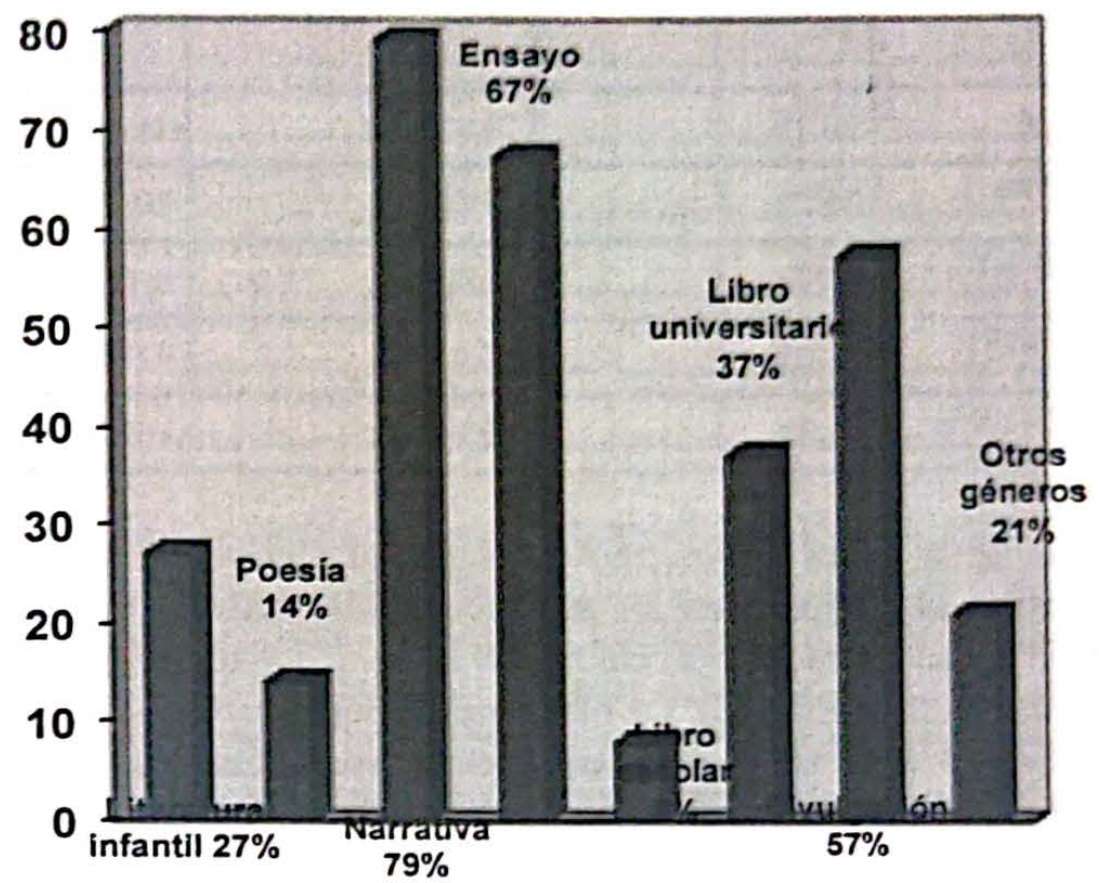

La traducción de textos literarios y humanísticos (el ensayo es el género estrella) es la más practicada. Dentro de la traducción de textos literarios, no obstante, es obligado matizar. La narrativa se consolida como el género más traducido, mientras que la lírica es un género muy minoritario y el dramático ni siquiera se menciona. Los textos de divulgación siguen de cerca a la narrativa y al ensayo, ya que su relativa rapidez de ejecución los hace económicamente apetitosos. Los polos representados por la traducción de poesía y la traducción de obras de divulgación reflejan, respectivamente, la alternativa entre la excelencia intelectual y el valor económico. La traducción de textos periodísticos y audiovisuales no se materializa en este estudio. 
CUADRO 1. Dedicación a diversos tipos de traducción (ACE Traductores 1997,43)

\begin{tabular}{|l|l|l|l|}
\hline $\begin{array}{l}\text { PORCENTAJE } \\
\text { DE DEDICA- } \\
\text { CION }\end{array}$ & $\begin{array}{l}\text { TRADUCCION } \\
\text { LITERARIA }\end{array}$ & $\begin{array}{l}\text { TRADUCCION } \\
\text { DE PRENSA }\end{array}$ & $\begin{array}{l}\text { TRADUCCION } \\
\text { TÉCNICA }\end{array}$ \\
\hline Ninguna & $10,2 \%$ & $73,4 \%$ & $46,4 \%$ \\
\hline Hasta 25\% & $15,7 \%$ & $19 \%$ & $19,7 \%$ \\
\hline Entre $25-50 \%$ & $9,9 \%$ & $4,7 \%$ & $8,4 \%$ \\
\hline Entre $50-75 \%$ & $10,9 \%$ & $1,5 \%$ & $9,5 \%$ \\
\hline Entre $75-100 \%$ & $53,3 \%$ & $1,5 \%$ & $16,1 \%$ \\
\hline
\end{tabular}

Más de la mitad de los traductores encuestados (53,3\%) dedica la totalidad o la mayor parte de su trabajo a la traducción literaria entendida como la traducción de textos literarios y textos humanísticos (especialmente el ensayo). La otra mitad, por tanto, se dedica casi en exclusividad a la traducción de textos especializados $\mathrm{y}$, en menor medida, a la traducción de textos periodísticos. Las cifras no diferencian la traducción de textos audiovisuales pero en el estudio se menciona brevemente que en los últimos tiempos el sector de traductores dedicados a la traducción de este tipo de textos ha experimentado un notable crecimiento, sobre todo, en las comunidades autónomas con lengua propia.

Estos datos han sufrido modificaciones con el paso del tiempo, como se refleja en el siguiente cuadro: ${ }^{2}$

\footnotetext{
${ }^{2}$ Los datos del informe presentado en el LBTE 2010 proceden de las siguientes dos fuentes: a) las encuestas enviadas a 3167 traductores asociados a CEDRO (Centro Español de Derechos Reprográficos) en esa fecha, de las que se reciben completas un total de 614 (ACE Traductores 2010, 47), que arrojan información acerca de los objetivos del colectivo de traductores y de sus problemas específicos en el periodo 2009-2010, y b) las informaciones complementarias obtenidas de encuestas o estudios anteriores (ACE Traductores 2010, 45).
} 
CUADRO 2. Tipos de traducciones realizadas durante el desempeno de la profesión (ACE Traductores 2010, 52)

\begin{tabular}{|l|l|}
\hline Traducción de libros & $100 \%$ \\
\hline Traducción comercial & $40 \%$ \\
\hline Traducción para prensa & $27,5 \%$ \\
\hline Interpretación & $23,1 \%$ \\
\hline Traducción jurada & $12,5 \%$ \\
\hline Otros tipos de traducción & $35,5 \%$ \\
\hline
\end{tabular}

De acuerdo con la Ley de Propiedad Intelectual, ACE Traductores define la traducción de libros como la traducción de obras literarias, artísticas o científicas. Aunque el informe de ACE traductores no proporciona datos diferenciadores entre estas tres tipologías textuales, es importante destacar que todos los traductores encuestados (100\%) han traducido libros alguna vez $\mathrm{y}$, por tanto, han traducido tanto textos literarios y humanísticos como textos especializados (ACE Traductores 2010,52). A la traducción de libros le siguen la traducción comercial $(40 \%)$, otros tipos de traducción $(35,5 \%), y$, en último lugar, la traducción para prensa $(27,5 \%)$.

El volumen que adquiere la traducción comercial, que se realiza para agencias o clientes directos y que no genera derechos de autor (ACE Traductores 2010, 52), revela la importancia del factor económico en el sector, afectado, como todos, por la actual crisis financiera. Como afirma ACE Traductores (2010, 41), “La traducción es trabajo y mercado [...]. El valor económico en la traducción guarda una relación estrecha con la nueva situación de las comunicaciones en la globalización tecnológica de la información".

El genérico que incluye otros tipos de traducción hace referencia a la aparición de los nuevos soportes y muestra una importante tendencia al alza si se comparan los datos con la información correspondiente recogida en el estudio del año 1997 (ACE Traductores 2010, 52). 
Finalmente, a pesar de que la traducción para prensa se posiciona en el último lugar en el listado que nos ocupa, es muy importante destacar que la dedicación del traductor a este tipo de traducción supera también los datos de la encuesta del año 1997 (ACE Traductores 2010, 52).

Como se puede apreciar, con la llegada del siglo XXI, el panorama de la traducción de los géneros literarios en España está experimentando cambios notables cimentados principalmente en dos factores: las nuevas tecnologías y el estilo de vida contemporáneo.

Por una parte, el acceso económicamente competitivo a las nuevas tecnologías y su cada vez más intuitivo manejo fomentan la necesidad de su consumo. Por otra parte, la deriva hacia un estilo de vida marcado por la inmediatez de la información y la escasez de tiempo provocan la necesidad de creación de nuevos formatos que enmarquen las actividades ordinarias. Ambas necesidades se ven condicionadas, a su vez, por la situación de crisis económica, política, social y de valores que se está viviendo desde el comienzo de siglo a nivel internacional. En el tema que nos ocupa, podemos concretar esta situación en dos actividades editoriales específicas que afectan al mercado de la traducción literaria en España.

En primer lugar, nos referimos al fenómeno de los microrrelatos. Como comentan Roas (2010) y Vals (2010), en los últimos veinte o treinta años se ha comenzado a tomar conciencia del desarrollo de un nuevo género literario, el microrrelato, que, no obstante, encuentra sus raíces en modalidades narrativas previas. El microrrelato, también conocido como microcuento, minificción, microficción, cuento brevísimo o minicuento, se puede definir como una construcción narrativa literaria cuya principal característica es la brevedad de su contenido. En este sentido, entronca con la tradición genérica fundamental, de forma que puede relacionarse con varias etiquetas de la tríada clásica de las categorías genéricas (el AFORISMO en la lírica, el CUENTO en la épica o la LOA en la dramática, por ejemplo), pero, al mismo tiempo, entronca por forma y/o por contenido con la clasificación propuesta en este trabajo para el estudio de los géneros literarios en relación con su traducción, esto es, con los textos humanísticos (APOTEGMA, REFRÁN, MÁXIMA, AFORISMO, GREGUERÍA...), los textos periodísti- 
cos (NOTICIA, SUELTO...) y los textos audiovisuales (SERIES, ANUNCIOS...). Pese a los recelos existentes en torno a su entidad como género literario independiente, su creación y su difusión son una realidad actual ante la que el traductor literario no puede quedar indiferente.

En segundo lugar, hablamos de la autoedición. Plataformas virtuales como Amazon Kindle Direct Publisher (KDP), Bubok o Lulu, ${ }^{3}$ entre otras, ofrecen la posibilidad de autoeditar libros en formato electrónico o en papel de forma económicamente rentable para los autores y con plazos de publicación casi inmediatos. Esta práctica editorial también sufre de recelos teóricos, pero a partir de ella muchos cazatalentos literarios (los llamados scouts literarios) descubren verdaderas joyas editoriales que, de haber seguido el circuito editorial tradicional a través de agentes literarios, de premios o del contacto directo con editoriales, tardarían en ver la luz mucho más tiempo, en el mejor de los casos. La autoedición convierte la traducción literaria en una profesión permanentemente actualizada e inmediata, abierta a la difusion de nuevos géneros literarios.

\section{CIERRE}

La profesión del traductor literario en España se amolda necesariamente a la producción editorial y al mismo tiempo participa activamente de ella. La evolución de las categorías genéricas tradicionales en función de las necesidades derivadas de los nuevos tiempos requieren del traductor literario una continua actualización de su competencia literaria, principalmente de los conocimientos derivados del uso instrumental de las nuevas tecnologías y de su actitud positiva ante la renovación de las formas genéricas inherentes a cada cultura.

${ }^{3} \mathrm{~V}$. los siguientes enlaces para más información respecto a sus políticas editoriales: $<$ https:// kdp.amazon.com/self-publishing/signin>, <http://www.bubokes/> y $<$ http://www.lulu.com/ $>$. 


\section{REFERENCIAS BIBLIOGRÁFICAS}

ACE TRADUCTORES, Libro Blanco de la traducción en España, Madrid, ACE Traductores, 1997.

- Libro Blanco de la traducción en España, Madrid, ACE Traductores, 2010.

AGost, Rosa, Traducción y doblaje: palabras, voces e imágenes, Barcelona, Ariel, 1999.

Bustos GISBERT, José M., "Análisis discursivo de la noticia periodística", en CORTÉS ZABORRAS, Carmen; HERNÁNDEZ GUERRERO, Ma José (coords.), La traducción periodística, Cuenca, Ediciones de la Universidad de Castilla-La Mancha, 2005, págs.17-88.

Bustos GISBERT, José M., Arquitextura: fundamentos discursivos del texto escrito en español, Ediciones Universidad de Salamanca, 2013.

ChaUME VARELA, Frederic, "La pretendida oralidad de los textos audiovisuales y sus implicaciones en traducción", en AGOST, Rosa; CHAUME, Frederic (eds.), La traducción en los medios audiovisuales, Castellon, Universitat Jaume 1, 2001, págs. 33-46.

FONTCUBERTA, Mar de, La noticia. Pistas para percibir el mundo, Barcelona, Paidos, 1993.

GALLEGO ROCA, Miguel, Traducción y Literatura: Los estudios literarios ante las obras traducidas, Madrid, Júcar, 1994.

GARCIA BERRIO; HUERTA CALVO, Javier, Los géneros literarios: sistema e historia, Madrid, Cátedra, 1992.

GARCía IZQUIERDO, Isabel, "Los géneros y las lenguas de especialidad", en ALCARAZ VARÓ, E.; MATEO MARTíneZ. J.; YUS RAMOS, F. (eds.), Las lenguas profesionales y académicas, Barcelona-Alicante, Ariel-IULMA, 2007, págs. 119-125.

GARCía PEINADO, Miguel Ángel, "La traducción como género literario en el Renacimiento francés", en Entreculturas, Universidad de Málaga, 1, 2009, págs. 107-123.

GomIs, Lorenzo, "Gèneres literaris y gèneres periodístics", en Periodística, Revista Acadèmica, Barcelona, Societat Catalana de Comunicació, Universitat Pompeu Fabra, 1, 1989, págs. 129-141.

HeRNADI, Paul, Teoría de los géneros, Barcelona, Antoni Bosch, 1978.

HERNÁNDEZ GUERRERO, Ma José, "La traducción de los géneros periodísticos", en CORTÉS ZABORRAS, Carmen; HERNÁNDEZ GUERRERO, Ma José (coords.), La traducción periodística, Cuenca, Ediciones de la Universidad de CastillaLa Mancha, 2005, págs. 89-173.

- "Técricas específicas de la traducción periodística", en Quaderns, Revista de traducción, Universitat Autònoma de Barcelona, 13, 2006, págs. 125-139.

- "La traducción periodística en los diarios españoles de información general", en PEGENAUTE, L.; DECESARIS, J.; TRICÁs, M.; BERNAL, E. (eds.), Actas 
del III Congreso Internacional de la Asociación Ibérica de Estudios de Traduccion e Interpretación. La traducción del futuro: mediación linguíistica y cultural en el siglo XXI. Barcelona 22-24 de marzo de 2007, Barcelona, PPU, 2, 2008, págs. 359-368. Versión electrónica disponible en:

<http://www.aiet.eu/pubs/actas/III/AIETI_3_MJHG_Traduccion.pdf>.

HURTADO ALBIR, Amparo, Traducción y Traductología. Introducción a la Traductología, Madrid, Cátedra, 2001.

JAKOBSON, Roman, Lingüística y Poética (est. prelim. Francisco Abad y trad. Ana M. ${ }^{a}$ Gutiérrez-Cabello), Madrid, Cátedra, [1958], 1988.

KARAM, Tanius, "La comunicación literaria. Notas para un debate teórico", en Espéculo, Revista de Estudios Literarios, Madrid, Universidad Complutense de Madrid, 31, 2006. Revista digital cuatrimestral disponible en < http://pendientedemigracion.ucm.es/info/especulo/numero31/comliter. html>.

MARTÍN DUQUE, Ireneo; FeRnÁNDEZ CUESTA, Marino, Géneros literarios. Iniciación a los estudios de literatura, Madrid, Playor, 1988.

MARTÍNEZ ALBERTOS, José Luis, "Lo primero, aprender a informar", en La Voz de la Escuela, Madrid, 1996, pág. 2.

MARTÍNEZ HERNANDO, Bernardino, "Alicia en el país de los géneros. Géneros periodísticos y géneros literarios", en Comunicación y Estudios Universitarios (Monográfico "Los géneros periodísticos en los medios de comunicación impresos, ¿ocaso o vigencia?”), Valencia, Universidad CEU San Pablo, 8, 1998, págs. 51-60.

MAYORAL ASENSIO, Roberto, "El espectador y la traducción audiovisual", en AGOST, Rosa; CHAUME, Frederic (eds.), La traducción en los medios audiovisuales, Castellón, Universitat Jaume I, 2001, págs. 33-46.

MAYORAL, José Antonio (ed.), Pragmática de la Comunicación Literaria, Madrid, Arco/Libro, 1999.

MERCADO LÓPEZ, Sebastián, (2004) "El análisis de géneros aplicado a la traducción: los prospectos de medicamentos en Estados Unidos y España", en Linguax, Revista de Lenguas Aplicadas Universidad Alfonso X el Sabio, Villanueva de la Cañada, Madrid: J. Ramón Trujillo, 2004. Versión electrónica disponible en <http:/ / www.uax.es/ publicacion/el-analisis-degeneros-aplicado-a-la-traduccion-los-prospectos-de-medicamentos.pdf>.

ONIEVA MORALES, Juan Luis, Introducción a los géneros literarios a través del comentario de textos, Madrid, Playor, 1992

ROAS, David et ál., Poéticas del microrrelato, Madrid, Arco Libros, 2010.

RODRÍGUEZ MORATÓ, Arturo, La problemática profesional de los escritores y traductores. Una visión sociológica, Barcelona, ACEC, 1997.

RODRÍGUEZ PEQUEÑO, Francisco Javier, Ficción y géneros literarios (Los géneros literarios y los fundamentos referenciales de la obra), Universidad Autónoma de Madrid, 1995.

Futhark 9 (2014)

Enríquez y Mendoza, Los géneros literarios, 85-120

ISSN 1886-9300 
RODRíguez PuÉrtolas, Julio (ed.), Lengia Castellana y Literatura, Madrid, Akal, 2000.

SOKOLI, Stavroula, "Temas de investigación en traducción audiovisual: La definición del texto audiovisual", en ZABALBEASCOA, Patrick et ál. (eds). La traducción audiovisual: investigación, enseñanza y profesión, Granada, Editorial Comares, 2005, págs. 177-185.

SPANG, Kurt, Géneros literarios, Madrid, Síntesis, 2000.

TOURY, Gideon, Los Estudios Descriptivos de Traducción y más allá. Metodología de la investigación en Estudios de Traducción (trad. y ed. Rosa RABADÁN y Raquel MERINO), Madrid, Cátedra, 2004, [1995].

VALLS, Fernando, Soplando vidrio y otros estudios sobre el microrrel 